\title{
Medication Adherence Analysis of Type 2 Diabetes Mellitus Patients
}

\section{Sulistyo Andarmoyo', Harmy bin Mohamed Yusoff², Berhanudin bin Abdullah ${ }^{3}$, Yuzana bint Mohd Yusop ${ }^{2}$}

${ }^{1}$ Faculty of Health Sciences, Muhammadiyah University of Ponorogo, East Java, Indonesia

2 Faculty of Medicine, Sultan Zainal Abidin University, Terengganu, Malaysia

${ }^{3}$ Faculty of Islamic Contemporary Studies, Sultan Zainal Abidin University, Terengganu, Malaysia

\section{Article Info}

Article History:
Accepted December 25th,
2019

Keywords:

Type 2 diabetes mellitus;

Adherence; Treatment

\section{Abstract}

\begin{abstract}
Adherence has an important role in therapy management in patients with type 2 Diabetes Mellitus. This research is to identify and analyze factors related to medication adherence. The design used in this study was a descriptive-analytic design with a cross-sectional approach. The population is type 2 Diabetes Mellitus sufferers of Prolanis Group in Primary Health Care Facilities in the Ponorogo Regency. A sample of 180 respondents was taken by purposive sampling technique. Variable $\mathrm{X}$ includes age, gender, education, occupation, income, and length of suffering. Variable Y was medication compliance with type 2 Diabetes Mellitus patients. Data collection used a Morisky Medication Adherence (MMAS-8) questionnaire and was analyzed using the Chi-Square test with a significant level of $\alpha<0.05$. From the results of the study, it was found that the factors of age, sex, education, employment, income and duration of suffering had a significant relationship with medication adherence for patients with type 2 diabetes mellitus. It is expected that health services develop family and communitybased service management. Researchers are further advised to develop programs to improve medication adherence.
\end{abstract}

\section{INTRODUCTION}

Diabetes mellitus is a group of metabolic diseases with hyperglycemia characteristic that occurs due to abnormalities in insulin secretion, insulin action, or both. Chronic hyperglycemia in diabetes is associated with long-term damage, and dysfunction of several organs, especially the eyes, kidneys, nerves, heart, and blood vessels, which cause various kinds of complications, including atherosclerosis, neuropathy, kidney failure, and retinopathy ${ }^{1}$.
At present, the prevalence of diabetes in the world reaches 230 million people and that number is up by $3 \%$ or an increase of 7 million people every year. In 2025 there are an estimated 350 million people who have diabetes mellitus in the world. The World Health Organization (WHO) says that half of the adults with diabetes in the world are in 5 countries; China, India, the United States, Brazil, and Indonesia ${ }^{2}$. Indonesia ranks 7 th with the highest number of people with diabetes mellitus in the world. The International Diabetes Federation (IDF) states that in 2016 Indonesia has around 9.1

Corresponding author:

Sulistyo Andarmoyo

sulistyoandarmoyo@gmail.com

South East Asia Nursing Research, Vol 1 No 3, December 2019

ISSN:2685-032X

DOI: https://doi.org/10.26714/seanr.1.3.2019.107-111 
million people with $\mathrm{DM}^{3}$. It is estimated that the number could increase to 12.4 million people in 2025 and reach 14.1 million in $2035^{2}$. One of the regions with the highest number of diabetics is East Java Province with a prevalence of DM sufferers of $2.1 \%$, which ranks 5th in the top 10 of diabetes mellitus prevalence in Indonesia 4 .

The success of DM management to prevent complications is achievable, primarily through adherence to pharmacological therapy. Compliance is a change in behavior according to the instructions given by the doctor in the form of exercise therapy, diet, treatment, and disease control. Indirectly, the level of medication adherence can be measured by the Morisky Medication Adherence Scale (MMAS)-8 questionnaire. The questionnaire is a method for assessing medication adherence in patients with chronic diseases, including diabetes that has been validated by WHO. Noncompliance with taking medication can lead to complications, the risk of hospitalization, and high costs 5 .

Adherence to the treatment of DM is quite important in the management of DM yet still a big problem 6 . The level of adherence of patients with type 2 DM which is still low compared to type 1 can be caused by polypharmacy and therapeutic regimens which are generally more complex, as well as drug side effects that arise during treatment ${ }^{6}$. Compliance with medication and taking medication in people with DM have a very important role in controlling blood sugar.

This study was conducted to determine the description of compliance with type 2 Diabetes Mellitus patients in the Prolanis (Chronic Disease Management Program) group in primary care facilities in Ponorogo Regency East Java Indonesia.

\section{METHODS}

The design used in this research is analytical descriptive design using a cross-sectional approach. The study was conducted from
April 15th to May 30th, 2019, in the Prolanis (Chronic Disease Management Program) group in the primary service facilities in Ponorogo Regency East Java Indonesia. The study sample of 180 patients with type 2 Diabetes Mellitus with inclusion criteria (male or female aged $\geq 18$ years; diagnosed with type 2 diabetes, received drug therapy, had attended a regular check-up at least one time, and was willing to take part in the study). Exclusion criteria are patients who have met the inclusion criteria but are pregnant and breastfeeding, illiterate; patients diagnosed with chronic kidney or liver disease and who undergo hemodialysis.

Data analysis was done descriptively by describing patient characteristics consisting of age, sex, last education, occupation, income, and duration or the length of suffering. Then tabulation is made. The compliance is measured using Morisky Medication Adherence 8 items (MMAS-8). It is said to be obedient if the total score of respondents answered "yes" on each questionnaire is $\leq 2$. It is said to be noncompliant if the total score of respondents answered "yes" on each questionnaire is 38.

Data were collected after obtaining patient approval from the Human Research Ethics Committee (UHREC) Sultan Zainal Abidin University Malaysia with Number: UnISZA.C / 2 / UHREC / 628-2 (85) on 8 April 2019 with UHREC code number: UnISZA / UHREC / 2018/46

\section{RESULTS}

Based on the results of the study in the table above, it can be seen that there are 125 people (69.4\%) are not compliant to the undergoing treatment programs and there are 55 people $(30.6 \%)$ who are compliant to the undergoing treatment programs.

Based on the age, the highest noncompliance is in the age range $>45$ years which is 115 people (63.9\%), based on the 
sex the highest non-compliance is female which reaches 115 people (63.9\%), based on education, the highest non-compliance is the low education patients with 125 people (69.4\%), based on occupation, the highest non-compliance is among working patients which is 125 people (69.4\%), based on income, the highest non-compliance is highincome patients with 67 people $(37.2 \%)$, based on length of suffering, the highest non-compliance patients are those who had a long duration of suffering $\leq 74(41.1 \%) 5$ years.

Table 1 Patient compliance based on patient demographic characteristics.

\begin{tabular}{|c|c|c|c|c|c|}
\hline \multirow[b]{2}{*}{ Indicators } & \multicolumn{4}{|c|}{ Compliance } & \multirow[t]{2}{*}{ p } \\
\hline & $\begin{array}{l}\text { Compl } \\
\text { iance }\end{array}$ & $\%$ & $\begin{array}{l}\text { Non- } \\
\text { Compl } \\
\text { iance }\end{array}$ & $\%$ & \\
\hline $\begin{array}{l}\text { Age } \\
>45 \text { years } \\
\leq 45 \text { years }\end{array}$ & $\begin{array}{l}22 \\
33 \\
\end{array}$ & $\begin{array}{l}12,2 \\
18,3\end{array}$ & $\begin{array}{c}115 \\
10\end{array}$ & $\begin{array}{c}63,9 \\
5,6\end{array}$ & $\begin{array}{l}0,0 \\
00\end{array}$ \\
\hline $\begin{array}{l}\text { Gender } \\
\text { Men } \\
\text { Women } \\
\end{array}$ & $\begin{array}{l}22 \\
33 \\
\end{array}$ & $\begin{array}{l}12,2 \\
18,3\end{array}$ & $\begin{array}{c}10 \\
115\end{array}$ & $\begin{array}{c}5,6 \\
63,9 \\
\end{array}$ & $\begin{array}{l}0,0 \\
00\end{array}$ \\
\hline $\begin{array}{l}\text { Education } \\
\text { Low } \\
\text { High }\end{array}$ & $\begin{array}{l}45 \\
10 \\
\end{array}$ & $\begin{array}{c}25,0 \\
5,6\end{array}$ & $\begin{array}{c}125 \\
0\end{array}$ & $\begin{array}{c}69,4 \\
0 \\
\end{array}$ & $\begin{array}{l}0,0 \\
00\end{array}$ \\
\hline $\begin{array}{l}\text { Occupation } \\
\text { Working } \\
\text { Not working }\end{array}$ & $\begin{array}{l}44 \\
11 \\
\end{array}$ & $\begin{array}{c}24,5 \\
6,1\end{array}$ & $\begin{array}{c}125 \\
0\end{array}$ & $\begin{array}{c}69,4 \\
0 \\
\end{array}$ & $\begin{array}{l}0,0 \\
00\end{array}$ \\
\hline $\begin{array}{l}\text { Income } \\
\text { Low } \\
\text { High }\end{array}$ & $\begin{array}{c}0 \\
55 \\
\end{array}$ & $\begin{array}{c}0 \\
30,6 \\
\end{array}$ & $\begin{array}{l}58 \\
67 \\
\end{array}$ & $\begin{array}{l}32,2 \\
37,2 \\
\end{array}$ & $\begin{array}{l}0,0 \\
00\end{array}$ \\
\hline $\begin{array}{l}\text { Suffering } \\
\text { Duration } \\
>5 \text { years } \\
\leq 5 \text { years }\end{array}$ & $\begin{array}{c}7 \\
48\end{array}$ & $\begin{array}{c}3,9 \\
26,7\end{array}$ & $\begin{array}{l}51 \\
74\end{array}$ & $\begin{array}{l}28,3 \\
41,1\end{array}$ & $\begin{array}{l}0,0 \\
00\end{array}$ \\
\hline
\end{tabular}

\section{DISCUSSION}

During the \pm 6 weeks of data collection using a questionnaire it was found that as many as 672 Type 2 DM patients have received treatment at Prolanis (Chronic Disease Management Program) in primary health care facilities in Ponorogo District. There are around 12 of them who refuse to become respondents so that only about 180 respondents meet the inclusion and exclusion criteria of the study.

Based on the results of research conducted it can be seen that age, sex, education, occupation, income and length of suffering have a significant relationship to medication adherence to type 2 Diabetes Mellitus sufferers.

\section{Age Factors}

The results of the study showed that the majority of respondents were over 45 years old. These results are consistent with the results of Riskesdas which shows the majority of Type 2 DM patients aged 56-64 years ${ }^{7}$. The high number of type 2 DM sufferers at age-susceptible is influenced by several causes, among others, pancreatic beta cells have decreased function in old age which can be influenced by the level and duration of insulin resistance ${ }^{8}$.

Chi-square statistical test results showed that the age factor had a significant value of $0,000$ ( $p>0.05)$, indicating that the correlation between age and medication adherence was significant. According to the older the age, the lower the level of compliance. This is due to the physiological function of the decline due to aging ${ }^{10}$.

\section{Gender Factor}

The highest proportion of respondents based on sex is female. The prevalence of DM in women is higher than in men, especially in type $2 \mathrm{DM}$, because they are likely to be obese due to an increase in body mass index, monthly cycle/menstruation, and menopause which cause them to experience fat accumulation in the body due to the hormonal process ${ }^{11}$.

The results of chi-square the statistical test showed that the sex factor had a significant value of 0,000 ( $p>0.05)$, indicating that the correlation between sexes with medication adherence was significant. States that gender is related to different life roles and behaviors between men and women in society. In maintaining health, women usually take better care of their health than men $^{12}$. 


\section{Educational Factors}

Educational factors have a significant value of 0,000 ( $p>0.05)$, indicating that the correlation between education and medication adherence is significant. The results of this study are the same as ${ }^{13}$, that education has a significant relationship with medication adherence in patients with diabetes mellitus with a value of $p=0.012$. The level of education affects a person's learning process, the higher the education obtained, the easier the person gets information, and the more information obtained, the more knowledge will be obtained ${ }^{14}$.

\section{Occupational Factors}

Someone who does not work is more at risk of developing DM than those who work. That is because the group does not work are generally lacking in physical activities so that the burning of calories in the body or metabolic processes are not as high as the working group.

The results of the chi-square statistical test showed that the occupational factor had a significant value of 0,000 ( $p>0.05$ ), indicating that the correlation between work and medication adherence was significant. According to other research, a person's work affects physical activity. ${ }^{15}$ The group not working tends to lack physical activity so that there is no movement of the limbs, this can make them easier to experience DM.

\section{Income Factor}

Income factor has a significant value that is $0,000$ ( $p>0.05)$, indicating that the correlation between income and medication adherence is significant. Economic status influences someone to conduct self-care management. State that the high cost of treatment in type 2 Diabetes Mellitus patients is still an important reason in terms of preventing suboptimal levels of adherence ${ }^{16}$.

\section{The Suffering Duration Factor or The Length of Illness}

The length or the duration of illness affects compliance toward treatment. Barriers to adherence can be caused by complex treatment regimens, duration of treatment, multi-therapy, drug efficacy, and lack of information provided by health care providers. Other barriers are related to socioeconomic problems, memory disorders, psychological problems, and personal beliefs ${ }^{17}$.

Chi-square statistical test results indicate that the duration of the length of suffering has a significant value of $0,000(p>0.05)$, indicating that the correlation between the duration of the length of suffering from adherence to taking medication is significant. Patients with type 2 diabetes mellitus with comorbidities will indirectly consume more complex types of drugs. Complex types of drugs such as the number of drugs, frequency of administration, dosage forms, as well as special drug administration instructions can trigger noncompliance.

\section{CONCLUSION}

The factors of age, sex, education, employment, income and duration of suffering have a significant relationship with medication compliance with type 2 Diabetes Mellitus patients in the Prolanis Group in Primary Health Care Facilities.

\section{ACKNOWLEDGMENTS}

We wish to express our appreciation to all respondents who participated in this study for valuable assistance during data collection.

\section{CONFLICTS OF INTEREST}

Neither of the authors has any conflicts of interest that would bias the findings presented here. 


\section{REFERENCES}

1. American Diabetes Association. (2014). Standars of medical care in diabetes-2014. Diabetes Care. 2014;37(1):S14-S80. doi:10.2337/dc14-S014

2. Tandra, H. (2017). Segala Sesuatu yang Harus Anda Ketahui Tentang DIABETES: Panduan Lengkap Mengenal dan Mengatasi Diabetes dengan Cepat dan Mudah (Edisi Kedua). (Gramedia Pustaka Utama).

3. International Diabetes Federation. Diabetes Atlas 7th ed in (2015).

4. Kemenkes RI. (2014) Situasi dan Analisis Diabetes. Pusat Data dan Informasi Kementerian Kesehatan RI 2 (2014). doi:24427659

5. Srikartika, V. M., Cahya, A. D., Suci, R., Hardiati, W. \& Srikartika, V. M. (2015). Analisis Faktor Yang Memengaruhi Kepatuhan Penggunaan Obat Pasien Diabetes Melitus Tipe 2. J. Manaj. dan Pelayanan Farm. 6, 205-212.

6. Puspitasari, A.W, (2012), Analisis Efektivitas pemberian Booklet Obat Terhadap Tingkat Kepatuhan Ditinjau Dari Kadar Hemoglobin Terglikasi (HbA1c) dan Morisky Medication Adherence Scale (MMAS)-8 Pada Pasien Diabetes Melitus Tipe 2 Di Puskesma Bakti Jaya Kota Depok,Tesis Program Studi Magister Ilmu Kefarmasian, Universitas Indonesia, Depok.

7. Riskesdas, (2013). Riset Kesehatan Dasar. Badan Penelitian Dan Pengembangan Kesehatan Kementerian Kesehatan RI, Jakarta.

8. Goldenberg, R., Punthakee, Z., (2013), Definition, Classification and Diagnosis of Diabetes, Pre diabetes and Metabolic Syndrome, Can J Diabetes, 37:8-11.

9. Brown, M.T., \& Bussell, J.K. (2011). Medication Adherence: WHO Care. Mayo Clin Proc, 86 (4). 304-314
10. Rosyida, L.dkk. (2015). Kepatuhan Pasien Pada Penggunaan Obat Antidiabetes dengan Metode Pill Count dan MMAS-8 di Puskesmas Kedurus Surabaya. Jurnal Farmasi Komunitas. Vol. 2(2) : 36-41

11. Muflikhatin S. K \& Fahrudin. (2014). Hubungan antara usia, riwatay keturunan dan pola makan dengan kejadian diabetes mellitus tipe 2 di Ruang Flamboyan Rsud Abdul Wahab Sjahranie Samarinda.

12. Novian A. (2013). Kepatuhan Diit Pasien Hipertensi. Jurnal Kesehatan Masyarakat Volume 1, Nomor 9, 2013.

13. Sweileh, W. M., Zyoud, S. H., Abu, R. J., Deleq, M. I., \& Enaia, M. I. (2014). Influence of Patients Disease Knowledge and Beliefs About Medicines on Medication Adherence: Findings From A Cross-Sectional Survey Among Patients With Type 2 Diabetes Mellitus in Palestine. BMC Public Health, 14, 1-8.

14. Notoatmodjo, S. (2012). Pendidikan dan Perilaku Kesehatan. (Rineka Cipta).

15. Palimbunga, T. M., Ratag. B. T., Kaunang, W. P. J., (2017). Faktor-Faktor yang Berhubungan dengan Kejadian Diabetes Melitus Tipe 2 di Rsu Gmim Pancaran Kasih Manado. 1-11.

16. Abbas A., Kachela B., Arif J.M., Tahir K.B., Shoukat N. and Ali N.B., (2015), Assessment Of Medication Adherence And Knowledge Regarding The Disease Among Ambulatory Patients With Diabetes Mellitus in Karachi, Pakistan, Journal of Young Pharmacists, 7 (4), 328-340.

17. Currie CJ, Peyrot M, Morgan CL, Poole CD, Jenkins-Jones S, Rubin RR, et al. (2012) The impact of treatment noncompliance on mortality in people with type 2 diabetes. Diabetes Care. 2012;35(6):1279-84. doi:10.2337/dc11-1277 